\title{
OBITUARIES
}

\section{Prof. Eric S. Horning}

ON November 14, 1959, British cancer research lost one of its prominent figures by the death of $\mathrm{Dr}$. E. S. Horning, professor of experimental pathology in the University of London at the Chester Beatty Research Institute. Australian by birth, he served as a volunteer with the Imperial Forces during the First World War, and went to Oxford in 1920 to start his professional career in the honours school of comparative anatomy and zoology.

Having taken his degree, he wont into research, first in Melboume with Prof. Agar and later with A. Fischer in Berlin-Dahlem and E. V. Cowdry and A. Carrel in the United States. From this period stem numerous papers dealing with tho behaviour of mitochondria and othor cytological problems. The excellence of his early work was soon recognized. In 1932 he contributed by invitation an article on the enzymatic function of mitochondria to "Ergebnisse der Enzymforschung", and in 1941 he wrote in G. Bourne: "Cytology and Cell Physiology" the chapter on micro-incineration and the inorganic constituents of cells, a subject on which he was an authority.

Armed with a comprehensive knowledge of cytology and histology, and well versed in the methods of tissue culture, in 1933 he returned to England, the country he loved more than any other, where he spent the rest of his life but for the years of the Second World War, during which he served again with great distinction in the Armed Forces.

In 1933 Dr. Horming joined the staff of the Imperial Cancer Research Fund as a Beit Fellow; when six years later the outbreak of war called him from tho bench he had made his name as a cancer investigator A series of brilliant papers had appeared in which Cramer and Horning recorded their original observa. tions, shedding new light on the pathogenesis of the tumours of the breast, pituitary and thymus, and establishing the role of the adrenals in the development of these tumnurs.

In 1947 Dr. Horning accepted an invitation by Prof. A. Haddow to go to the Chester Beatty Research Institute as reader in experimental pathology. There he worked until the end, his scientific activities continuing unabated in spite of periods of indifferent health. Testimony to his persistent interest in the endocrinological aspects of cancer are the chapters in "Oestrogens and Neoplasia", his contribution to "Causation of Cancer" in the British Medical Bulletin 1958, and his papers on the experimental cancers of the prostate and the œstrogen-induced tumours of the kidney. Although from 1936 onward the role of hormones in neoplasia was the main theme of his endeavours, by his studies of the action of carcinogenic compounds on grafted tissues he made notable contributions to chemical carcinogenesis. Besides, his considerable experience with the pathology of the experimental and spontaneous tumours of rodents made him an invaluable collaborator in many projects of the Chester Beatty Research Institute. Inter alia, he described with Boyland the tumours induced by nitrogen mustards in mice, and with Alexander the reaction of the subcutaneous tissue of the rat to implanted plastic films.
Anybody who had the privilege to visit Dr. Horning in his laboratory and to look at some of his slides could only admire the beauty of his histological preparations, and was no longer astonished by the excellence of the photomicrographs which adorn his papers. The high quality of the material on which Dr. Horning's results were based and the elegance of his techniques rather than ingenuity of speculation were the basis of the high esteem he enjoyed among his colleagues at home and abroad. But, above all, few men had his gift for friendship and a heart so warm and generous. Only those who have worked with him know how easy he made life for his col laborators and how much he did unselfishly to further the work of the Institute. For his human and scientific qualities the memory of Eric Horning will be cherished in many lands.

\section{F. BIfLSChowsky}

\section{Mr. W. E. Dick}

WITH the sudden death of William E. Dick at the carly age of forty-five, scientific journalism has lost one of the greatest exponents of this now rapidly expanding and increasingly important field-a field which shows signs of becoming to-day almost as important to the scientist, as a means of keeping him informed of developments in other fields as well as his own, as to the intelligent layman who wishes to loarn about scientific and technological progress. He was successively editor of Discovery $(1945-56)$, British Chemical Engineering (1956-58), and Chemistry and Industry, the journal of the Society of Chemistry and Industry. Prior to that he had held posts on the Grantham Journal (1941) and the South Western Star, which he joined in 1942. For a brief period he then worked as assistant editor to Chemical Age, before joining Discovery in a full-time capacity in September 1944.

William Dick was born at Walthamstow on July 12,1914 , and was educated at King's School, Wimbledon, where he took a State scholarship at the age of fifteen to the Imperial College of Science and Technology to read biology. Although he left the Imperial College before his degree was completed, his training was not purely journalistic, for he later became a qualified scientist, taking an extemal B.Sc. degree at the Chelsea Polytechnic in 1942. He was also elected a Fellow of the Linnean Society.

During the War he served with the Auxiliary Fire Service during the first months, and then at the British Expeditionary Force, Royal Army Service Corps Hoadquarters in France before being evacuated when France surrendered. Then he transferred to one of the camouflage units of the Royal Enginoors at Farnham. He entered journalism in August 1941, after being invalided out from the Army.

When Bill Dick became editor of the newly revived Discovery, science writing was still, as I was made only too well aware on numerous occasions, regarded as a 'bastard art', more often than not despised by the seientist and badly handled by the Press. By setting a standard of journalistic and scientific reporting that raised Discovery from being a relatively unknown journal to one that had a readership throughout the world, and was renowned and highly 